\title{
Balancing the oral microbiome based on the hydrogen peroxide-producing bacteria
}

\author{
Young Je Ahn', Yun-Sun Kim , Ji-Hyung Kim, Hyojin Kim², Nae-Kyu Kang ${ }^{1}$ \\ ${ }^{1}$ Core-Technology Research Institute, $L G H \& H$ research center, Korea \\ ${ }^{2}$ Oral Health $R \& D$ Division, $L G H \& H$ research center, Korea
}

\begin{abstract}
Objectives: Prebiotic oral care products with ingredients expected to encourage the function of beneficial bacteria and inhibit the growth of harmful bacteria are continuously being released. However, it is still unclear which bacteria are beneficial. In order to develop prebiotic oral care products, we tried to clarify the beneficial bacteria among the commensal bacteria and find some ingredients helpful for balancing the microbiome.

Methods: Oral probiotics such as Lactobacillus reuteri have known to produce hydrogen peroxide $\left(\mathrm{H}_{2} \mathrm{O}_{2}\right)$, which can attack anaerobic pathogenic bacteria. Therefore, we defined and selected beneficial bacteria depending on their properties of $\mathrm{H}_{2} \mathrm{O}_{2}$ production by cultivating the Streptococcus species on the Prussian blue agar plate. Through understanding the feature of beneficial good bacteria, we developed a prebiotic oral care product and confirmed it was useful for balancing the oral microbiome.

Results: $S$. gordonii, $S$. oralis and $S$. thermophilus produced $\mathrm{H}_{2} \mathrm{O}_{2}$, otherwise $S$. sangunis, $S$. salivarius, $S$. mutans did not. In addition, we found that $\mathrm{H}_{2} \mathrm{O}_{2}$ producing bacteria were present in the human saliva, but there was an individual difference indicating that oral environment could regulate the microflora. $S$. gordonii secreted $\mathrm{H}_{2} \mathrm{O}_{2}$ when it is superior to the competition with $S$. mutans. It was regulated by oral environments such as $\mathrm{pH}$ of saliva, energy sources, antibacterials and anti-gingivitis active ingredients.

Conclusions: Based on our results, we developed a toothpaste containing alternative energy sources; stevia and xylitol, a mild anionic surfactant; sodium methyl cocoyl taurate (SMCT) and anti-gingivitis active ingredients; Centella asiatica extract, Zea mays oil unsaponifiables, Magnolia officinalis bark extract. It was helpful for S. gordonii to prevail and produce $\mathrm{H}_{2} \mathrm{O}_{2}$ in vitro. Finally, we found that 2-week application of prebiotic toothpaste reduced the ratio of anaerobic periodontal pathogens; $81 \%, 42 \%$ and $52 \%$ reduction for $P$. gingivalis, $T$. forsythia and $T$. denticola, respectively.
\end{abstract}

Keywords: Hydrogen peroxide, S. gordonii, Stevia, Xylitol, SMCT, Centella asiatica extract, Zea mays oil unsaponifiables, Magnolia officinalis bark extract

Copyright (C) 2021. Korean Academy of Preventive Dentistry. All rights reserved.

This is an Open Access article distributed under the terms of the Creative Commons Attribution Non-Commercial License (http://creativecommons.org/licenses/ by-nc/4.0) which permits unrestricted non-commercial use, distribution, and reproduction in any medium, provided the original work is properly cited. 